\title{
DifFICULTIES FACED BY NURSING STAFF WHEN CARING FOR A DYING PATIENT
}

Renata Dziubaszewska ${ }^{1 A, E, F}$, Dawid Makowicz ${ }^{1 A, B, C, D, F}, N^{2}$ atalia Makowicz ${ }^{2 A, B, C}$

${ }^{1}$ Nursing Department, Carpathian State College in Krosno, Poland

${ }^{2}$ Internal Disease Ward, Subcarpatian Hospital of John Paul II in Krosno, Poland

Authors' contribution:

A. Study design/planning • B. Data collection/entry $\bullet$ C. Data analysis/statistics $\bullet$ D. Data interpretation $\bullet$ E. Preparation of manuscript $\bullet$ F. Literature analysis/search $\bullet$ G. Funds collection

\author{
Address for correspondence: \\ Dawid Makowicz \\ Nursing Department \\ Carpathian State College in Krosno \\ Rynek 1, 38-400 Krosno, Poland \\ e-mail: david1990@onet.pl \\ SUBMITTED: 10.11 .2020 \\ ACCEPTED: 16.02 .2021 \\ DOl: https://doi.org/10.5114/ppiel.2021.110449
}

\begin{abstract}
Introduction: Nursing is a profession that is particularly exposed to contact with human death. Caring for a dying patient requires the nursing team to be in contact with his/her pain and suffering. In their work, nurses must deal with many difficulties resulting from this beautiful but at the same time demanding profession.

Aim of the study: Assessment of difficulties faced by nursing staff in caring for a dying patient.

Material and methods: The study was carried out using the diagnostic survey method, by means of a questionnaire, which consisted of 36 single-choice and 4 multiple-choice questions. The study included a group of 581 female nurses and 13 male nurses working in hospital wards in the Subcarpatian voivodeship. The material was collected in 2018. Statistical analysis was performed using the SPSS program.

Results: The largest percentage of respondents (58.4\%) believed that the greatest difficulty in caring for a dying patient is the lack of time that should be devoted to the patient. Nursing staff felt fear of the death of a loved one (63.3\%). Over $48 \%$ of the surveyed nurses believed that informing the patient about their imminent death should depend on the patient's condition and external conditions at work in the ward.

Conclusions: Professional nursing care for a terminally ill patient should focus primarily on pain relief and ensuring contact with his/her family.

Key words: nursing, patient, death.
\end{abstract}

\section{INTRODUCTION}

From the beginning of human history, death has been associated mainly with suffering, pain, loss of a loved one, and many other negative emotions. Despite the fact that it is an inseparable element of human existence, it cannot be ignored. Mankind has a thorough knowledge of the dying process but is still not able to stop it. Actions taken towards the dying person may still focus only on extending their life and helping them by reducing physical, mental, and spiritual pain, which in the context of a terminally ill patient is a very important issue [1].

The profession that has a special relationship with death is the nurse. Among other professions, the nursing staff spend most of their time with the dying patient during hospitalization, staying with them both when their condition improves and when it worsens, when the available options for saving a life are exhausted. In the terminal phase, the most important thing is to nurture and care for the sick and to provide them with the optimal living conditions, including reducing ailments and ensuring comfort.
These tasks are not easy because, apart from the phenomenon of death itself, the nurse must face a number of other challenges related to contact with the patient and his/her family, as well as professional duties that must also be performed in relation to all other patients staying on the ward. With constant contact with death and the inability to have any impact on improving the patient's health, the nursing team may struggle with stress, fear, and growing frustration, and they may ask themselves questions about the meaning of human existence and the existence in the world. Therefore, it is extremely important to identify the main difficulties that accompany the work of nurses with a dying patient, in order to be able to at least partially minimize them or, if possible, eliminate them [2].

\section{AIM OF THE STUDY}

Self-assessment of difficulties in caring for a dying patient by nursing staff with particular attention to the influence of age and education of nurses in this aspect. 


\section{MATERIAL AND METHODS}

The study was carried out using the diagnostic survey method by means of a questionnaire, which consisted of 26 single-choice and 4 multiple-choice questions and 10 record questions. The study included a group of 594 nurses (581 female and 13 male nurses) working in hospital wards, where nursing staff often have contact with dying patients (Nursing and Treatment Centre, Palliative Care Department, Internal, Cardiology, Neurology, ICU). The respondents worked in hospitals in Rzeszów, Krosno, Jasło, and Strzyżów. In the group of respondents, 34.8\% were people aged $22-29$ years, $50 \%$ aged $30-49$ years, and $15.2 \%$ over 50 years. A large part of the surveyed group had worked in the profession for less than 10 years ( $45.9 \%), 16 \%$ of the respondents had worked in the profession for between 11 and 20 years, while $38.1 \%$ had worked in the profession for over 20 years. The material was collected in 2018. Statistical analysis was performed using the SPSS program. All relationships were considered statistically significant when $p \leq 0.05$. The research complies with the requirements of the Helsinki Declaration.

\section{RESULTS}

The highest percentage of the surveyed nurses (58.4\%) believed that the greatest difficulty in caring for a dying patient is the lack of time that should be devoted to the patient. Another important problem is the aggressive behaviour of the family (28.9\%), the lack of mental preparation (23\%), and the feeling of fear and helplessness (20.6\%) (Fig. 1).

The largest number of respondents among the nursing staff were afraid of the death of a loved one (63.3\%), a much smaller percentage of respondents felt fear of their own death (9.6\%). Among the examined group, $8.9 \%$ did not feel fear of death at all. Statistical analysis showed that with the increase of the age of nurses up to the age of 60 years, the percentage of respondents who felt fear of their own death decreased, while after the age of 30 years, the number of people who felt anxious about the possibility of their loved ones dying decreased with age. The presented reduction in the percentage of people experiencing the fear of death with increasing age was statistically significant $(p=0.03)$ (Table 1$)$.

The highest percentage of the surveyed nurses (48.1\%) believed that the decision to inform patients about their upcoming death should depend on the patient's condition and the external conditions in the ward. A significant percentage of respondents (35.7\%) believed that a patient, regardless of his/her condition, should know the prognosis of his/her health. The smallest number of respondents (5.9\%) believed that the patient should not be informed about their impending death for the sake of his/her psychological comfort. The study showed that the percentage of nurses who expressed the opinion that the patient should be informed about their impending death in every health situation decreased significantly with the increase of age. The presented results are significant from the statistical point of view $(p<0.001)$ (Table 2).

In the opinion of the nursing staff, the most ethical management of a terminally ill patient is to ensure that they die in a dignified manner. Such an opinion, regardless of the level of education, was expressed by $98 \%$ of the surveyed nurses. Only $1.5 \%$ of the respondents considered that such a patient should be treated with all possible measures in order to save and sustain life. The research material proved that, along with the increase in the education level, there is a growing percentage of nurses who have the conviction that the most ethical treatment of terminally ill patients is to provide them with conditions of dying in dignity; at the same time, there is a decrease the percentage of respondents who believe that all measures (persistent therapy) to save life at all costs should be used ( $p=0.008$ ) (Table 3 ).

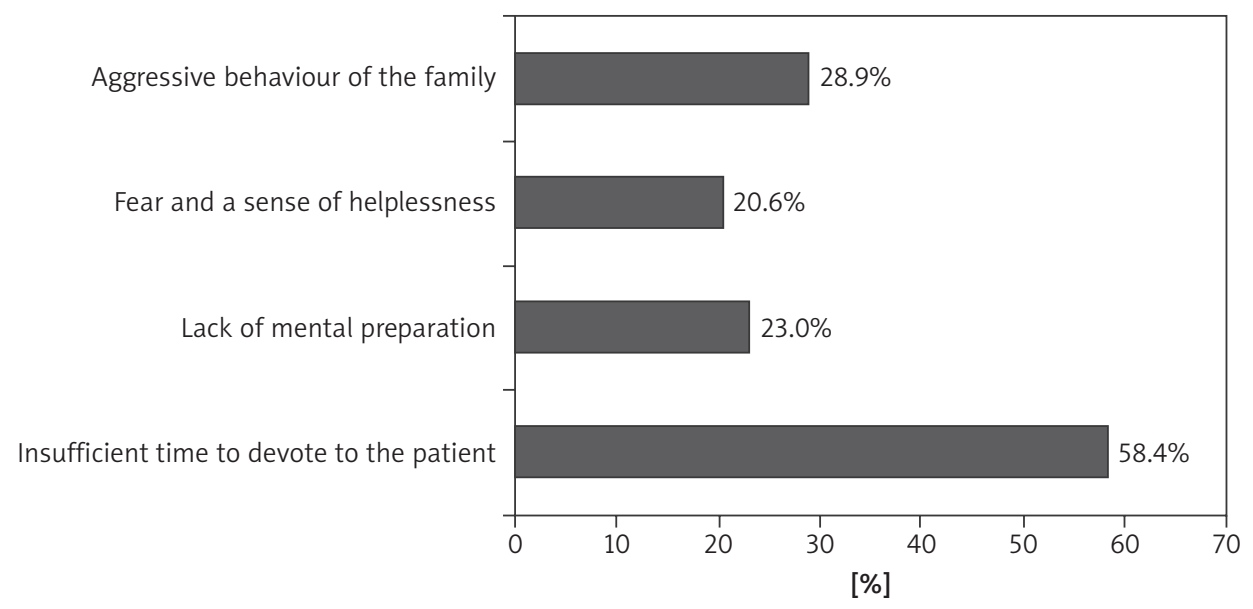

Figure 1. The most important obstacles in caring for a dying patient reported by the nursing staff 
Table 1. Nursing staff's feeling of fear of death

\begin{tabular}{|c|c|c|c|c|c|c|c|}
\hline \multirow{2}{*}{\multicolumn{2}{|c|}{$\begin{array}{l}\text { Do you have a fear of death due to } \\
\text { frequent contact with death of patients? }\end{array}$}} & \multicolumn{5}{|c|}{ Age (years) } & \multirow[t]{2}{*}{ Overal } \\
\hline & & $22-29$ & $30-39$ & $40-49$ & $50-59$ & 60 and more & \\
\hline \multirow{2}{*}{$\begin{array}{l}\text { Yes, but I'm more afraid of my } \\
\text { own death }\end{array}$} & $n$ & 24 & 10 & 16 & 4 & 3 & 57 \\
\hline & $\%$ & 11.7 & 9.2 & 8.5 & 4.9 & 30.0 & 9.6 \\
\hline \multirow{2}{*}{$\begin{array}{l}\text { Yes, I am afraid of the death } \\
\text { of a loved one }\end{array}$} & $n$ & 134 & 79 & 115 & 44 & 4 & 376 \\
\hline & $\%$ & 65.0 & 72.5 & 61.2 & 54.3 & 40.0 & 63.3 \\
\hline \multirow[t]{2}{*}{ Yes, before death itself } & $n$ & 16 & 7 & 16 & 15 & 1 & 55 \\
\hline & $\%$ & 7.8 & 6.4 & 8.5 & 18.5 & 10.0 & 9.3 \\
\hline \multirow{2}{*}{$\begin{array}{l}\text { Yes, I am afraid of an } \\
\text { unexplained phenomenon }\end{array}$} & $n$ & 4 & 3 & 6 & 6 & 1 & 20 \\
\hline & $\%$ & 1.9 & 2.8 & 3.2 & 7.4 & 10.0 & 3.4 \\
\hline \multirow[t]{2}{*}{ I don't know } & $n$ & 10 & 4 & 12 & 7 & 0 & 33 \\
\hline & $\%$ & 4.9 & 3.7 & 6.4 & 8.6 & 0.0 & 5.6 \\
\hline \multirow[t]{2}{*}{ I am not afraid } & $n$ & 18 & 6 & 23 & 5 & 1 & 53 \\
\hline & $\%$ & 8.7 & 5.5 & 12.2 & 6.2 & 10.0 & 8.9 \\
\hline \multirow[t]{2}{*}{ Overall } & $n$ & 206 & 109 & 188 & 81 & 10 & 594 \\
\hline & $\%$ & 100.0 & 100.0 & 100.0 & 100.0 & 100.0 & 100.0 \\
\hline
\end{tabular}

$p=0.03$, Cramer's V $=0.12, \chi^{2}=34.08(d f=20)$

$n$-the number of people who gave an answer, $p$, Cramer's $V, \chi^{2}$ - statistically significant

Table 2. Nursing staff's opinion on informing the patient about their impending death

\begin{tabular}{|c|c|c|c|c|c|c|c|}
\hline \multirow{2}{*}{\multicolumn{2}{|c|}{$\begin{array}{l}\text { Do you think the patient should be } \\
\text { informed about their impending death? }\end{array}$}} & \multicolumn{5}{|c|}{ Age (years) } & \multirow[t]{2}{*}{ Overall } \\
\hline & & $22-29$ & $30-39$ & $40-49$ & $50-59$ & 60 and more & \\
\hline \multirow{2}{*}{$\begin{array}{l}\text { Yes, he/she should know what } \\
\text { awaits him/her }\end{array}$} & $n$ & 94 & 42 & 53 & 23 & 0 & 212 \\
\hline & $\%$ & 45.6 & 38.5 & 28.2 & 28.4 & 0.0 & 35.7 \\
\hline \multirow[t]{2}{*}{ It depends on the situation } & $n$ & 85 & 48 & 105 & 44 & 4 & 286 \\
\hline & $\%$ & 41.3 & 44.0 & 55.9 & 54.3 & 40.0 & 48.1 \\
\hline \multirow{2}{*}{$\begin{array}{l}\text { The truth should not be revealed } \\
\text { for the sake of the patient's } \\
\text { mental comfort }\end{array}$} & $n$ & 10 & 5 & 11 & 5 & 4 & 35 \\
\hline & $\%$ & 4.9 & 4.6 & 5.9 & 6.2 & 40.0 & 5.9 \\
\hline \multirow[t]{2}{*}{ I'm not sure } & $n$ & 17 & 14 & 19 & 9 & 2 & 61 \\
\hline & $\%$ & 8.3 & 12.8 & 10.1 & 11.1 & 20.0 & 10.3 \\
\hline \multirow[t]{2}{*}{ Overall } & $n$ & 206 & 109 & 188 & 81 & 10 & 594 \\
\hline & $\%$ & 100.0 & 100.0 & 100.0 & 100.0 & 100.0 & 100.0 \\
\hline \multicolumn{8}{|c|}{$p<0.001$, Cramer's $V=0.15, \gamma 2=42.15(d f=12)$} \\
\hline
\end{tabular}

Table 3. The most ethical management of terminally ill patients according to nursing staff

\begin{tabular}{|c|c|c|c|c|c|c|}
\hline \multirow{2}{*}{\multicolumn{2}{|c|}{$\begin{array}{l}\text { What do you think is the most ethical way } \\
\text { of dealing with a dying terminal patient? }\end{array}$}} & \multicolumn{4}{|c|}{ Type of school } & \multirow[t]{2}{*}{ Overall } \\
\hline & & $\begin{array}{l}\text { Medical high } \\
\text { school }\end{array}$ & $\begin{array}{l}\text { Post-secondary } \\
\text { school }\end{array}$ & $\begin{array}{l}\text { Bachelor's } \\
\text { degree }\end{array}$ & $\begin{array}{l}\text { Master's } \\
\text { degree }\end{array}$ & \\
\hline \multirow{2}{*}{$\begin{array}{l}\text { Provide him/her with dignified } \\
\text { conditions for dying }\end{array}$} & $n$ & 46 & 37 & 267 & 232 & 582 \\
\hline & $\%$ & 92.0 & 97.4 & 98.2 & 99.1 & 98.0 \\
\hline \multirow{2}{*}{$\begin{array}{l}\text { Take all measures to support and save } \\
\text { life }\end{array}$} & $n$ & 4 & 1 & 3 & 1 & 9 \\
\hline & $\%$ & 8.0 & 2.6 & 1.1 & 0.4 & 1.5 \\
\hline \multirow[t]{2}{*}{ I have no opinion } & $n$ & 0 & 0 & 2 & 1 & 3 \\
\hline & $\%$ & 0.0 & 0.0 & 0.7 & 0.4 & 0.5 \\
\hline \multirow[t]{2}{*}{ Overall } & $n$ & 50 & 38 & 272 & 234 & 594 \\
\hline & $\%$ & 100.0 & 100.0 & 100.0 & 100.0 & 100.0 \\
\hline \multicolumn{7}{|c|}{$p=0.008$, Cramer's V $=0.12, \chi^{2}=7.30(d f=6)$} \\
\hline
\end{tabular}




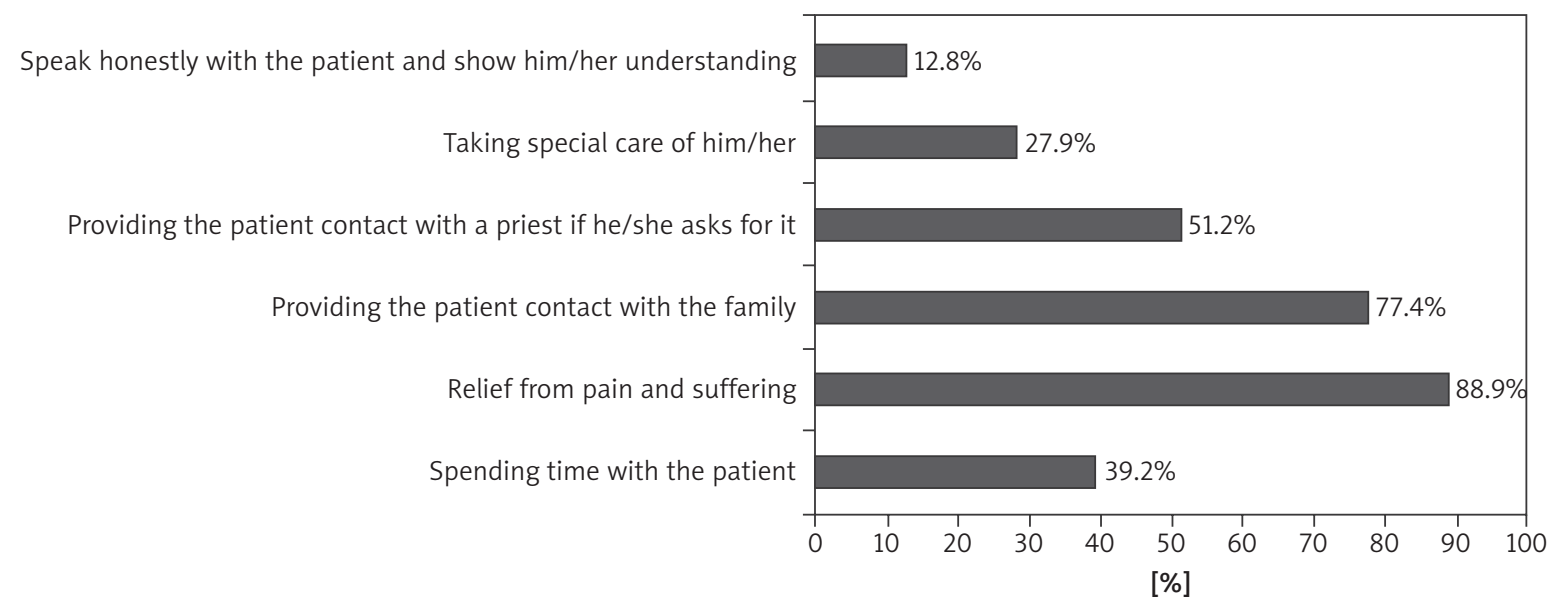

Figure 2. The most important elements of caring for a dying patient in the opinion of the surveyed nurses

Table 4. The rightness of the use of persistent therapy in the opinion of the respondents

\begin{tabular}{|c|c|c|c|c|c|c|}
\hline \multirow{2}{*}{$\begin{array}{l}\text { Applying persistent therapy in hospital } \\
\text { is your opinion }\end{array}$} & & \multicolumn{4}{|c|}{ Type of school } & \multirow[t]{2}{*}{ Overall } \\
\hline & & $\begin{array}{l}\text { Medical high } \\
\text { school }\end{array}$ & $\begin{array}{l}\text { Post-secondary } \\
\text { school }\end{array}$ & $\begin{array}{l}\text { Bachelor's } \\
\text { degree }\end{array}$ & $\begin{array}{l}\text { Master's } \\
\text { degree }\end{array}$ & \\
\hline \multirow[t]{2}{*}{ Extending the suffering } & $n$ & 32 & 30 & 211 & 200 & 473 \\
\hline & $\%$ & 64.0 & 78.9 & 77.6 & 85.5 & 79.6 \\
\hline \multirow{2}{*}{$\begin{array}{l}\text { Extending life, there is always } \\
\text { a chance of recovery }\end{array}$} & $n$ & 9 & 7 & 32 & 17 & 65 \\
\hline & $\%$ & 18.0 & 18.4 & 11.8 & 7.3 & 10.9 \\
\hline \multirow[t]{2}{*}{ I have no opinion } & $n$ & 9 & 1 & 29 & 17 & 56 \\
\hline & $\%$ & 18.0 & 2.6 & 10.7 & 7.3 & 9.4 \\
\hline \multirow[t]{2}{*}{ Overall } & $n$ & 50 & 38 & 272 & 234 & 594 \\
\hline & $\%$ & 100.0 & 100.0 & 100.0 & 100.0 & 100.0 \\
\hline \multicolumn{7}{|c|}{$p=0.008$, Cramer's V $=0.12, \chi^{2}=17.32(d f=6)$} \\
\hline
\end{tabular}

The most important elements in caring for a dying patient, in the opinion of the respondents, are as follows: relieving pain and suffering (88.9\%), providing the patient with contact with the family $(77.4 \%)$, and enabling the patient to contact a priest (51.2\%). The respondents attached the least importance to honest conversation and showing understanding to the patient (12.8\%) (Fig. 2).

Most of the nurses expressed a belief that the use of persistent therapy prolongs suffering (79.6\%), while $10.9 \%$ of the respondents believed that there is always a chance for recovery. Statistical analysis showed that people with higher education more often treat persistent therapy as prolonging suffering and less often as prolonging life $(p=0.008)$ (Table 4).

\section{DISCUSSION}

Death is very often a taboo subject, but it is also a phenomenon with which nurses struggle in their professional work. It carries many unpleasant emotions and obstacles that make working with a dying patient even more difficult. At the same time, com- munication difficulties arise in the relations between the dying patient, his/her family, and accompanying members of the medical staff. In the author's study, the respondents paid special attention to the problem of insufficient time that could be devoted to a terminal patient (58.4\%). An even higher percentage of respondents indicates the presence of the same problem in the Blaževičienè study, in which $84 \%$ of nurses recognised the problem of the inability to spend time with a dying patient due to excessive work duties. The obtained results are also confirmed by the work of Morawska-Jóźwiak, who in her research showed that $65 \%$ of the nursing staff complained about the volume of duties they have to fulfill, which means that they are not able to devote enough time and attention to their patients. On the other hand, Liang's analyses showed that due to the lack of time on duty, nursing staff face a significant problem regarding the proper planning of time devoted to the care of the dying person and treatment activities undertaken towards other patients [3-5].

A significant obstacle for the studied group was aggressive behaviour of the family, which was no- 
ticed by $28.9 \%$ of the surveyed nurses. The existence of this problem is also confirmed by Lickiewicz in his study, in which $23 \%$ of nursing staff admitted that they had encountered demanding behavior and aggression from the patient's families in the past. An even greater percentage of such situations can be observed in the Frydrysiak study, where as many as $88 \%$ of respondents encountered such behavior from patients' families. Despite the fact that the Frydrysiak study was conducted in the Hospital Emergency Department, where the specificity of work is different than in the departments where the original study was conducted, it emphasizes the importance of the presented problem in an extremely important way. A study by Moghaddam on the problems faced by the nursing team when working with a patient who has been diagnosed with brain death showed that family members very often blame the nursing staff for the condition of the patient and show aggression towards them.

Norouzadeh noted in his study that bad news about the patient's health is a cause of aggression for the patients' families and unjustified demands from health care workers [6-9].

Another issue analyzed in the author's study was the fear of death among nursing staff. It was revealed that the nursing staff were most afraid of the death of a loved one $(63.3 \%)$, while $9.6 \%$ were afraid of their own death. An even higher result was achieved in the Niedojad's study, in which $82 \%$ of nurses declared fear of the death of a loved one. In the study by Śleziona, the increased anxiety accompanying the nursing staff while being with dying patients was also associated with the possibility of the death of a loved one (51.7\% of respondents). Dadfar in his analyses showed that members of nursing staff were much more afraid of the death of other people than of their own death [10-12].

In the author's study, it was observed that with the increase of age, the percentage of respondents who feare for their own death and that of a loved one decreased $(p=0.03)$. Gama, examining the attitude of nurses to death, showed that older nurses had a significantly higher level of acceptance of death than younger nurses $(p<0.0001)$. Moreover, in his analyses, Peters proved that age among nursing staff is the most important determinant influencing the reduction of the fear of death, and with the increase of age, the phenomenon of its acceptance occurs $[13,14]$.

The highest percentage of respondents (48.1\%) believed that the decision to inform the patient about their imminent death should depend on the situation with which the medical personnel are dealing. Among the respondents, $35.7 \%$ believed that the hospitalized person has the right to obtain information about their health condition and prognosis in any situation, while $5.9 \%$ believed that the truth should not be revealed to the patient for his/her psychological comfort. Rucińska's research and analyses showed that only $5 \%$ of the surveyed medical students believed that it is possible to refrain from informing the patient about an unfavorable prognosis; moreover, $99 \%$ of respondents wanted to know the truth about the diagnosis and bad prognosis. It is also important that the conducted research showed that only $31 \%$ of hospitalized patients felt that they were properly informed about their health condition. Moreover, Kassa presented that the majority of nurses from Denmark and Norway (64\%) believed that concealing information or lying to patients about their prognosis is unethical $[15,16]$.

Another aspect examined was the presentation of the most ethical treatment of a terminally ill patient. According to the vast majority of respondents (98\%), the most moral behaviour is to provide the patient with the conditions for a dignified death. Also, in the study by Niedojad, the highest percentage of respondents (97\%) believed that the most important nursing action undertaken with regard to dying patients should be to guarantee them proper conditions for a dignified death. Meier, who analyzed articles on this topic, showed that for $85 \%$ of the studies analyzed, the most important issues for healthcare professionals in caring for dying patients were pain control and comfort as a prerequisite for a "good death". Dzierżanowski, in his work on dignity in dying, emphasizes in particular that every human being has the right to respect for his or her dignity, and this should be particularly remembered when dealing with a dying patient. The fundamental rule of modern medicine is to have a subjective, not objective, approach to each patient. Moreover, in the proprietary study, the percentage of people convinced of the rightness of this procedure increased with their level of education $(p=0.008)$. It was shown that with the increase in education of the surveyed nurses, the percentage of people perceiving persistent therapy as prolonging suffering increased, and the number of people treating it as prolonging the patient's life decreased $(p=0.008)$. In the study by Kiełbasa-Siennicki, it was shown that with increasing education, the percentage of respondents who were convinced that it is better moral behaviour to ensure conditions of a dignified death rise, rather than to conduct persistent therapy. The result obtained was close to the limit of statistical significance $(p=0.0902)[10,17-19]$.

The surveyed nursing staff believed that the most important care activities aimed at ensuring conditions of a dignified death are as follows: relieving pain and suffering (88.9\%), and providing the patient with contact with their family (77.4\%) and with a priest $(51.2 \%)$

An even higher result was achieved in the Niedojad study, in which $99 \%$ of the respondents indicated that it was an extremely important issue in caring 
for a dying patient to bring relief from suffering and pain to the patient. In his research, Bazaliński showed that, in the opinion of nursing teams, a patient with an unfavourable health prognosis in the last days of his/her life should be provided with the best possible conditions for dying in a dignified manner.

Relief of unpleasant sensations such as pain, dyspnoea, anxiety, fever (78\%), showing respect (66\%), and enabling constant contact with the family (63\%) were considered the most important. Taking these actions is perceived mainly as professional patient care $(83 \%)$. Fadare, conducting his research, showed that for $90.1 \%$ of people employed in the nursing profession, the treatment of pain and its symptoms is a significant problem when dealing with hospitalized patients in a terminal state. Rui-Shuang also recognized that the most important aspects of medical care for a dying patient are pain relief and undertaking nursing care. The highly significant issue of saying goodbye to a dying person is also presented in Życzkowska's analyses, which showed that $81 \%$ of respondents expressed the will to meet their loved ones for the last time (family and friends). In addition, Ayed's study raised an important issue, namely that $44.8 \%$ of nurses believed that the family should be directly involved in the care of a dying family member in hospital [10, 20-24].

Nursing staff mainly perceived the use of persistent therapy as prolonging the patient's suffering (79.6\%). Yekefallah's analyses showed that people working in the medical sector often perceived persistent therapy as causing additional pain and suffering to the patient, which only results in prolonging painful life. In addition, it is emphasized that a significant amount of medical resources are consumed without achieving the desired effect. In research conducted among medical staff, Cybulska showed that $71.4 \%$ of respondents were against the use of persistent therapy, while $96.1 \%$ of people believed that treatment should be abandoned in a situation where it do not bring tangible benefits but only prolonged suffering. In the Bazaliński study, $69 \%$ of respondents were of the opinion that in the event of a lack of effects of persistent therapy or, on the contrary, when it causes suffering, it should be abandoned. Moreover, Rostami emphasized that withdrawing from persistent therapy cannot be treated as killing the patient, but instead as ensuring dignified conditions for dying, because it is the most ethical procedure in the event of imminent death [20, 25-27].

\section{CONCLUSIONS}

Modern nursing care faces an important challenge in reorganizing the work of nurses so that more time can be given to the patient in the terminal phase of the disease.
The growing problem in nurses work with terminally ill patient is aggressive behaviour of patient's family.

Nursing staff caring for dying patients are emotionally burdened, and they transfer their emotions to private life, which manifests itself in fear for the death of a loved one.

Professional nursing care for a terminally ill patient should focus primarily on pain relief and ensuring contact with his/her family.

\section{Disclosure}

The authors declare no conflict of interest.

\section{References}

1. Becler R. Ewolucja operacyjnej definicji śmierci człowieka. Prawo i Medycyna 2015; 59: 52-59.

2. Boruń T. Rola pielęgniarki w opiece paliatywnej i hospicyjnej - opis przypadku Adama. Piel Zdr Publ 2011; 1: 289-296.

3. Blaževičienè A, Newland JA, Čivinskienè V, et al. Oncology nurses' perceptions of obstacles and role at the end-of-life care: cross sectional survey. BMC Palliat Care 2017; 16: 74.

4. Morawska-Jóźwiak B, Olejniczak P, Rasmus P. Wypalenie zawodowe personelu pielęgniarskiego pracującego w oddziałach szpitalnych. Pielęgniarstwo Polskie 2016; 61: 317-323.

5. Liang L, Hu L. Nurses' experience of taking care of dying patients in hospice care. Department of Health and Caring Sciences, Lishui University 2018; 14-16.

6. Lickiewicz J, Piątek J. Doświadczanie agresji w pracy pielęgniarskiej. Sztuka Leczenia 2014; 3-4: 11-21.

7. Frydrysiak K, Ejdukiewicz J, Grześkowiak M. Agresja pacjentów i ich bliskich wobec personelu Szpitalnego Oddziału Ratunkowego. Anestezjologia i Ratownictwo 2016; 10: 46-52.

8. Moghaddam MY, Manzari ZS, Heydari A, et al. The nursing challenges of caring for brain-dead patients: A qualitative study. Nurs Midwifery Stud 2018; 7: 116-121.

9. Norouzadeh R, Anoosheh M, Ahmadi F. Iranian nurses' perceptions of the conditions of the families with terminally ill patients: family in limbo. Nurs Midwifery Stud 2019; 8: 155-161.

10. Niedojad K, Rybka M, Rezmerska L, et al. Śmierć i umieranie w opinii personelu pielęgniarskiego. Pielęgniarstwo w Opiece Długoterminowej 2016; 3: 12-18.

11. Śleziona M, Krzyżanowski D. Postawy pielęgniarek wobec umierania i śmierci pacjenta. Piel Zdr Publ 2011; 1: 217-223.

12. Dadfar M, Lester D. The reliability, validity, and factorial structure of the collett-lester fear of death scale in a sample of Iranian nurses. Int J Med Res Health Sci 2016; 5: 306-317.

13. Gama G, Vieira M, Barbosa F. Factors influencing nurses' attitudes toward death. Int J Palliat Nurs 2012; 18: 267-273.

14. Peters L, Cant R, Payne S, et al. How death anxiety impacts nurses' caring for patients at the end of life: a review of literature. Open Nurs J 2013; 7: 14-21.

15. Rucińska M, Osowiecka K, Kocbach T, et al. Studenci medycyny wobec informowania pacjentów o niekorzystnym rozpoznaniu i rokowaniu. Palliat Med Pract 2018; 12: 1-7.

16. Kassa H, Murugan R, Zewdu F, et al. Assessment of knowledge, attitude and practice and associated factors towards palliative care among nurses working in selected hospitals. BMC Palliat Care 2014; 13: 1-11.

17. Meier E, Gallegos J, Montross-Thomas L, et al. Defining a good death (successful dying): literature review and a call 
for research and public dialogue. Am J Geriatr Psychiatry 2016; 24: 261-271.

18. Dzierżanowski T, Binnebesel J. Godność w umieraniu. Med Paliat 2019; 11: 156-162.

19. Kiełbasa-Siennicki E, Marczewski K. Analiza postaw personelu pielęgniarskiego wobec uporczywej terapii. Aspekty Zdrowia i Choroby 2018; 3: 91-110.

20. Bazaliński D, Marciniec I, Sałacińska I, et al. Doświadczenie uporczywej terapii w pracy pielęgniarek pracujących w oddziałach intensywnej terapii - doniesienie wstępne. Anestezjologia i Ratownictwo 2018; 12: 52-61.

21. Fadare J, Obimakinde A, Olaogun D, et al. Perception of nurses about palliative care: experience from south-west Nigeria. Ann Med Health Sci Res 2014; 4: 723-727.

22. Rui-Shuang Z, Qiao-Hong G, Feng-Qi D, et al. Chinese oncology nurses' experience on caring for dyingpatients who are on their final days: A qualitative study. Int J Nurs Stud 2015; 52: 288-296.

23. Życzkowska J. „Dobra śmierć”, a więc jaka? Oczekiwania pacjentów w ostatnich dniach życia. Medycyna Paliatywna w Praktyce 2016; 10: 48-53.

24. Ayed A, Sayej S, Harazneh L, et al. The Nurses' knowledge and attitudes towards the palliative care. J Educ Pract 2015; 6: 91-99.

25. Yekefallah L, Ashktorab T, Manoochehri H, et al. Nurses' experiences of futile care at intensive care units: a phenomenological study. Glob J Health Sci 2015; 7: 235-242.

26. Cebulska V, Koźlak V, Dybalski P. Wiedza i opinie personelu medycznego oddziałów anestezjologii i intensywnej terapii na temat prowadzenia uporczywej terapii. Med Paliat 2019; 11: 170-179.

27. Rostami S, Jafari H. Nurses' perceptions of futile medical care. Mater Sociomed 2016; 28: 151-155. 